\title{
Evaluasi Program Pengelolaan Lembaga PAUD di Kabupaten Serang
}

\author{
Wicka Yunita Dwi Utami ${ }^{\varpi_{1}}$, Martini Jamaris², Sri Martini Meilanie ${ }^{3}$ \\ Pendidikan Anak Usia Dini, Universitas Negeri Jakarta \\ DOI: $\underline{10.31004 / \text { obsesi.v4i1.259 }}$
}

\begin{abstract}
Abstrak
Penelitian ini bertujuan memberikan informasi mengenai evaluasi pengelolaan lembaga PAUD di Taman Kanak-Kanak dan Raudatul Athfal di Kabupaten Serang dengan menggunakan model evaluasi CIPP (context, input, process, product). Penelitian ini berfokus kepada komponen konteks yaitu kurikulum; komponen input yaitu struktur organisasi, peserta didik, pendidik dan tenaga kependidikan; komponen proses yaitu perencanaan pembelajaran, sarana dan prasarana, dan pembiayaan; dan komponen produk yaitu pengawasan dan tindak lanjut. Menggunakan desain penelitian kualitatif. Setelah data kualitatif didapat untuk melihat kepastian proses evaluasi, maka data kualitatif diolah atau dianalisis ke dalam kuantitatif. Teknik pengumpulan data dilakukan melalui wawancara, observasi dan dokumentasi. Subyek penelitian ini adalah TKS Al-Hidayah dan RA Darur Rohmat. Hasil penelitian menunjukkan bahwa pendidik dan tenaga kependidikan perlu meningkatkan kompetensi yang dimiliki serta kepedulian dari pengawas atau pembina lembaga dan instansi terkait dalam mengawasi dan membina lembaga untuk peningkatan mutu pendidikan.
\end{abstract}

Kata Kunci: evaluasi program; pengelolaan; lembaga paud

\begin{abstract}
The purpose of this research is to provide information concerning Early Childhood Learning Center (PAUD) evaluation management in kindergartens and Raudatul Athfal in Serang District using the CIPP evaluation model (context, input, process, product). This research discusses some context aspects including curriculum; input aspects examining organizational structure, students, educators and education staff; process planning, planning and infrastructure, and financing; and aspects of the product, that is the supervision and followup. Used a qualitative research design. After the qualitative data is obtained to observe the evaluation process, the qualitative data is processed or analyzed into quantitative. Data collection techniques are done through interviews, observation and documentation. The subjects of this research are TKS Al-Hidayah and RA Darur Rohmat. The results show that educators and education personnel need to improve the competencies needed. The attention of supervisors or supervisory institutions and related institutions also need to be developed to improve the quality of education.
\end{abstract}

Keywords: program evaluation; management; Early Childhood Learning Center.

Copyright (c) 2019 Wicka Yunita Dwi Utami, Martini Jamaris, Sri Martini Meilanie

$\triangle$ Corresponding author :

Email Address : drdadan19@gmail.com (Jln. Pemuda I Rawamangun, Jakarta Timur)

Received 6 August 2019, Accepted 14 September 2019, Published 4 October 2019 


\section{PENDAHULUAN}

Saat ini, pendidikan memiliki banyak tantangan seiring semakin berkembangnya zaman, keberagaman budaya, persaingan keuangan dan perkembangan teknologi, sehingga akan berpengaruh terhadap sistem dan kebutuhan pendidikan yang harus diberikan kepada peserta didik, terutama untuk peserta didik dalam Pendidikan Anak Usia Dini (PAUD). PAUD dengan kualitas yang baik dapat memberikan manfaat dalam jangka pendek dan panjang bagi kehidupan anak. Sebagaimana pada penelitian yang dilakukan oleh Kodarni bahwa dalam mengelola sebuah lembaga pendidikan di tingkat apa pun perlu adanya pengelolaan yang baik (Kodarni, 2016) Hal tersebut juga didukung pada penelitian yang dilakukan oleh Ridha, Markhamah dan Darsinah bahwa tanpa adanya pengelolaan yang baik, tidak mungkin tujuan pendidikan dapat diwujudkan secara optimal, efektif, dan efisien (Ridho, Markhamah, \& Darsinah, 2015).

Adanya permasalahan bahwa belum ratanya jangkauan layanan PAUD dan kualitas pengelolaan PAUD. Berdasarkan Rencana Strategi Kementerian Pendidikan dan Kebudayaan Tahun 2015-2019 bahwa belum semua anak usia PAUD memperoleh layanan pendidikan, sebagaimana ditunjukkan dengan capaian APK PAUD yang baru sebesar 68,1\% pada tahun 2014. Kualitas penyelenggaraan PAUD pun masih harus ditingkatkan sejalan dengan peningkatan akses, antara lain dengan Standarisasi layanan PAUD (Pendidikan, Kebudayaan, \& Indonesia, 2019).

Masalah pada pengelolaan lembaga PAUD juga dapat dibuktikan pada hasil analisis akreditasi yang dilakukan oleh Badan Akreditasi Nasional Pendidikan Anak Usia Dini dan Pendidikan Nonformal Provinsi Banten (BAN PAUD dan PNF Provinsi Banten) tahun 2018. Hasil analisis capaian Standar Nasional Pendidikan di lembaga PAUD dengan rata-rata capaian terendah yaitu standar pengelolaan sebesar 58,04 dan Kabupaten/Kota di Provinsi Banten yang khusus memiliki capaian terendah pada standar pengelolaan yaitu Kabupaten Serang sebesar 49,43 dibanding 7 Kabupaten/Kota di Provinsi Banten (Profile BAN P Banten, n.d.). Maka data tersebut dapat menjadi dasar untuk pembenahan bagi pengelolaan lembaga PAUD dan perlu dilakukan penelaahan serta evaluasi terkait penyebab rendahnya standar pengelolaan di lembaga PAUD Kabupaten Serang tersebut.

Selain itu, hasil wawancara dengan Kepala Bidang PAUD dan PNF Dinas Pendidikan dan Kebudayaan Kabupaten Serang pada Bulan April 2019, bahwa tahun 2018 tidak adanya pelatihan-pelatihan yang diselenggarakan bagi pendidik atau tenaga kependidikan PAUD dikarenakan tidak adanya anggaran khusus untuk kegiatan tersebut. Hal tersebut menjadi minim adanya pengetahuan tambahan dan kompetensi bagi pendidik atau tenaga kependidikan PAUD sebagai sumber daya utama penyalur pengetahuan kepada anak dan mengelola lembaga PAUD. Padahal dengan adanya PAUD yang sukses terdapat karakteristik yang telah ditentukan untuk menunjang kesuksesan tersebut dan kriteria tersebut dilihat dari kualitas atau mutu para pendidik dan sarana prasarana yang dimiliki (Sulusi maizu dan Indah Prabawati, 2016). Akan tetapi, pembinaan terhadap lembaga PAUD tetap dilakukan walaupun dengan jadwal yang belum jelas, akan tetapi hal tersebut masih perlu dievaluasi secara keseluruhan dikarenakan tidak seimbang dengan data hasil akreditasi yang didapat oleh lembaga PAUD, dimana Lembaga PAUD yang mendapatkan akreditasi baik tidak semua standar terpenuhi dengan baik, contoh pada pengelolaan yang mendapatkan hasil penilaian kurang baik, sedangkan pengelolaan lembaga yang baik akan berpengaruh terhadap kualitas Lembaga PAUD.

Di Indonesia, secara umum evaluasi pendidikan dilakukan melalui berbagai pendekatan seperti kegiatan Monitoring and Evaluation (Monev) atau supervisi yang dilakukan oleh pengawas pendidikan dan evaluasi pendidikan oleh Badan Akreditasi Nasional (BAN) melalui akreditasi. Namun demikian, evaluasi pendidikan tersebut masih belum efektif dalam memberikan umpan balik (feedback) bagi lembaga pendidikan untuk memahami apa saja yang menjadi area yang sudah baik dan area yang perlu ditingkatkan. Hal ini disebabkan oleh pendekatan evaluasi yang masih berbasis kuantitatif, dengan kata 
lain hasil evaluasi tersebut belum memberikan informasi yang komprehensif dan eksplisit mengenai kualitas setiap standar pendidikan di satuan pendidikan.

Sejalan dengan pentingnya evaluasi pendidikan, maka metode evaluasi digunakan untuk mengetahui kualitas program yang sudah dijalankan, yaitu dengan cara membandingkan dengan suatu standar yaitu standar PAUD yang telah ditetapkan pemerintah dan teori-teori yang menunjang pada unsur pengelolaan lembaga PAUD. Evaluasi meliputi hal-hal mengenai perencanaan, tenaga pendidik dan tenaga kependidikan, pelaksanaan pembelajaran, pelaksanaan pelayanan kesehatan, termasuk juga pengelolaan dan penilaian hasil belajar (Kasrani, 2016). Dalam hal ini, hal-hal tersebut akan dijadikan sebuah evaluasi. Salah satu pendekatan atau model evaluasi yang menyeluruh, komprehensif dan memberikan deskripsi yang mendetail terkait obyek atau variabel yang dievaluasi adalah model CIPP. Model CIPP (Context, Input, Process, Product) dikembangkan oleh Stufflebeam dan kawan-kawan pada tahun 1966.

Evaluasi terhadap pengelolaan lembaga PAUD yang akan diteliti terbagi ke dalam perencanaan program yaitu kurikulum, pengorganisasian yaitu tugas dan fungsi struktur organisasi peserta didik, pendidik, tenaga kependidikan, proses yaitu perencanaan pembelajaran, sarana dan prasarana dan pembiayaan, serta pengawasan dan tindak lanjut hasil pengawasan untuk menilai ketercapaian tujuan yang telah ditetapkan oleh lembaga PAUD. Dari hasil evaluasi tersebut, akan ditemukan hal-hal yang masih kurang dan hal-hal yang perlu dipertahankan dari program (Munthe, 2015). maka dari itu, evaluasi program terhadap pengelolaan lembaga PAUD sangat memungkinkan untuk dilaksanakan.

Evaluasi cara dalam menilai sesuatu. Evaluasi sebagai suatu proses menilai sesuatu berdasarkan kriteria atau standar obyektif yang telah ditetapkan untuk kemudian diambil keputusan atas obyek yang dievaluasi. Murray menjelaskan bahwa evaluasi adalah proses memberi makna pada pengukuran dengan menilai itu terhadap beberapa standar (Murray, 1990). Jadi evaluasi sebagai salah satu cara dalam menilai suatu obyek dan kemudian mengambil keputusan atas obyek tersebut untuk dapat ditentukan selanjutnya.

Evaluasi dilakukan atas kriteria-kriteria yang ditetapkan. Tujuan pelaksanaan evaluasi adalah untuk mengetahui sejauh mana proses yang terjadi dalam implementasi suatu obyek berdasarkan kriteria-kriteria yang ditetapkan, apakah obyek tersebut berhasil atau tidak, bermanfaat atau tidak sama sekali dan kemudian dijadikan landasan kebijakan keputusan apakah dilanjutkan atau diberhentikan. Dalam hal ini Arikunto dan Jabar menjelaskan ada empat kemungkinan kebijakan yang dapat dilakukan berdasarkan hasil evaluasi pelaksanaan program yaitu: 1) Menghentikan program, karena dipandang bahwa program tersebut tidak ada manfaatnya, atau tidak dapat terlaksana sebagaimana yang diharapkan; 2) Merevisi program, karena ada bagian-bagian yang kurang sesuai dengan harapan/ketentuan (terdapat kesalahan tetapi sedikit); 3) Melanjutkan program, karena pelaksanaan program menunjukkan bahwa segala sesuatu sudah berjalan sesuai dengan harapan, memberikan hasil yang bermanfaat; dan 4) Menyebarkan program (melaksanakan program di tempat lain atau mengulangi lagi program di lain waktu), karena program tersebut berhasil dengan baik, maka sangat baik jika dilaksanakan lagi di tempat dan waktu lain (Arikunto \& Jabar, 2009).

Pengelolaan sering diidentifikasi dengan istilah manajemen. Manajemen menurut Atmodiwiro diartikan sebagai proses merencanakan dan mengambil keputusan, mengorganisasikan, memimpin, dan mengendalikan sumber daya manusia, keuangan, fasilitas dan informasi guna mencapai sasaran organisasi dengan cara efisien dan efektif (Atmodiwiro, 2000). Jadi manajemen sebagai cara yang dilakukan guna mencapai sasaran organisasi dengan cara efektif dan efisien.

Evaluasi pengelolaan lembaga PAUD dilakukan dengan menilai kesesuaian lapangan dan acuan standar pengelolaan lembaga yang ditetapkan dan teori-teori yang mendukung. Dengan adanya evaluasi ini akan memperlihatkan hasil evaluasi sejauh mana standar pengelolaan lembaga PAUD diterapkan, dan selanjutnya akan dijadikan acuan 
dalam menentukan hal-hal yang harus dilakukan agar pengelolaan lembaga PAUD dapat terlaksana sesuai dengan yang diharapkan. Selain itu, evaluasi yang dilakukan disesuaikan dengan kondisi dan kebutuhan lembaga PAUD. The literature on supervision in the field reflects a variety of models which define the nature of supervision and staff development and suggests that, overall, early childhood programs are unique with respect to several factors in the supervisory context (Fleer, 1996). jadi pengawasan atau monitoring dilakukan dengan melihat berbagai faktor, kondisi dan kebutuhan lembaga PAUD, terutama kepada anak usia dini.

\section{METODOLOGI}

Metode penelitian ini menggunakan jenis penelitian evaluatif. Pada penelitian evaluatif, sumber data yang dilibatkan sebagai pemberi informasi adalah mereka yang memahami substansi objek yang diteliti (dievaluasi) karena variabel yang diamati adalah variabel faktual, bukan variabel konseptual seperti yang diamati pada penelitian nonevaluatif. Penelitian evaluasi ini menggunakan desain penelitian kualitatif. Setelah data kualitatif didapat untuk melihat kepastian proses evaluasi, maka data kualitatif diolah atau dianalisis ke dalam kuantitatif. Kedua metode ini masuk ke dalam kategori mixed method dengan model konvergen.

Penelitian dilaksanakan di lembaga PAUD yang terakreditasi oleh BAN PAUD dan PNF tahun 2018 yaitu di TK Al-Hidayah dengan status akreditasi B dan RA Darur Rohmat dengan status akreditasi $\mathrm{C}$. Teknik pengumpulan data yang digunakan dalam penelitian ini yaitu dokumentasi, observasi, angket dan wawancara. Pengumpulan data dilakukan untuk memperoleh informasi yang dibutuhkan agar mencapai tujuan penelitian.

Sumber pengumpulan data yang diambil melalui sumber primer dan sekunder. Sumber primer yaitu sumber data yang langsung memberikan data kepada pengumpul data meliputi wawancara dan observasi kepada guru dan Kepala PAUD, sedangkan sumber sekunder merupakan sumber yang tidak langsung memberikan data kepada pengumpul data, dalam hal ini bisa melalui studi terhadap dokumen yang sudah ada. Sedangkan teknik pengumpulan data angket yaitu teknik pengumpulan data dengan memberikan daftar pertanyaan kepada responden untuk diisi mengenai pertanyaan-pertanyaan permasalahan dalam penelitian dan yang menjadi responden dalam penelitian ini yaitu orang tua.

Penelitian ini menggunakan teknis analisis secara kualitatif dan dilakukan dalam 3 tahapan yaitu sebelum penelitian, selama penelitian dan setelah penelitian. Sebelum terjun ke lapangan, peneliti telah memiliki gambaran tentang apa yang akan diteliti. Analisis dilakukan pada data hasil studi pendahuluan atau data sekunder yang digunakan untuk menentukan fokus penelitian.

\section{HASIL DAN PEMBAHASAN}

Komponen context, berdasarkan hasil wawancara, peneliti mendapatkan informasi bahwa kurikulum disusun oleh lembaga sendiri dengan mengacu kepada peraturanperaturan yang sudah ditetapkan seperti Peraturan Menteri Pendidikan dan Kebudayaan Nomor 137 Tahun tentang Konsep Dasar, Peraturan Menteri Pendidikan dan Kebudayaan Nomor 146 Tahun 2014 tentang Kurikulum 13 PAUD dan landasan yuridis lainnya yang telah disebutkan di atas. Sesuai dengan hasil angket orang tua bahwa orang tua tidak terlibat dalam penyusunan kurikulum dah hanya mengetahui kegiatan-kegiatan apa saja yang akan anak lakukan dan terkadang kegiatan tersebut diinfokan 3 hari sebelum kegiatan dilaksanakan. Tetapi kurikulum yang ada belum dilakukan evaluasi kurikulum, jadi kurikulum yang digunakan tahun ini adalah kurikulum yang sebelumnya. Lembaga menganggap bahwa kurikulum yang ada masih bisa digunakan, maka dari tahun ke tahun memakai kurikulum yang sama hanya diganti tahun dan jadwal pelaksanaan perencanaan pembelajaran dan program/kegiatan, kecuali jika adanya perubahan aturan dalam acuan kurikulum PAUD.(Mendikbud \& Indonesia, 2014) Sedangkan evaluasi sangat penting dilakukan untuk menilai keberlanjutan atau digantinya kurikulum saat hasil evaluasi 
menghasilkan hasil yang tidak sesuai tujuan. Jadi kurikulum yang digunakan oleh kedua lembaga adalah kurikulum yang sudah digunakan sebelumnya, hanya saja mengganti waktu pembelajaran saja dan/atau kegiatan pembelajaran yang jika berubah. Seharusnya kurikulum terus diperbaharui berdasarkan usia, kondisi dan kebutuhan anak dan zaman agar tujuan pendidikan tercapai sebagaimana sesuai dengan penelitian Carol bahwa Kurikulum juga menyesuaikan dengan kebutuhan daerah dan perkembangan zaman agar kebermanfaatannya dapat tercapai (Carol, 2007).

Komponen input Berdasarkan hasil pengamatan di kedua lembaga tersebut memiliki struktur organisasi. Pembagian jabatan dalam struktur organisasi tersebut sesuai dengan kesepakatan bersama dan kepercayaan semua pihak untuk memegang jabatan masingmasing yang ditetapkan. Masing-masing lembaga memiliki jabatan sebagai Kepala PAUD, sekretaris, bendahara dan guru. Di TKS Al-Hidayah, Kepala PAUD merangkap sebagai sekretaris dan bendahara merangkap sebagai guru. Di Al-Hidayah, Kepala PAUD merangkap sebagai bendahara dan sekretaris merangkap sebagai guru. Walaupun rangkap jabatan, mereka tetap melaksanakan tugas secara profesional dan dapat membagi tugasnya dengan baik.

Jika melihat hasil angket orang tua bahwa orang tua mengetahui struktur organisasi dan tugas jabatan dalam lembaga walaupun dari pihak lembaga tidak menyosialisasikan. Tetapi sebaiknya pihak lembaga menyosialisasikan struktur organisasi sekolah atau memperkenalkan Kepala PAUD dan pendidik di lembaga tersebut agar orang tua dapat mengenalnya dengan jelas dan pasti. Selain itu dengan adanya rangkap jabatan dapat memberikan pemahaman kepada orang tua bahwa pekerjaan dapat dilaksanakan secara profesional.

Rekrutmen peserta didik bahwa tidak adanya publikasi edukasi dari pihak sekolah untuk menarik minat calon peserta didik baru. Publikasi yang dilakukan hanya sekedar informasi pembukaan pendaftaran bagi peserta didik tanpa diserta dengan sosialisasi tentang pentingnya pendidikan sejak anak usia dini atau sesuatu lain yang dapat menarik minat calon peserta didik baru atau pun orang tua. Publikasi yang hanya sekedar pengumuman pembukaan pendaftaran sudah berlangsung dari tahun ke tahun, hal inilah yang mungkin mengakibatkan rendahnya minta calon peserta didik yang dari tahun ke tahun menurun selain karena banyaknya Lembaga PAUD yang berdiri.

Dari sisi pengelompokan usia anak yang dilakukan kedua lembaga telah sesuai aturan yang ditetapkan yaitu pengelompokan usia 4-5 tahun dan 5-6 tahun berdasarkan usia anak sesungguhnya. Tetapi jika dari sistem perekrutan, sebaiknya kedua lembaga perlu lebih kreatif untuk menarik minat calon peserta didik dan orang untuk mendaftarkan diri.

Tetapi jika disesuaikan dengan rasio pendidik dan peserta didik, maka belum sesuai karena banyaknya jumlah peserta didik dibanding jumlah pendidik. Menurut Peraturan Menteri Pendidikan dan Kebudayaan Republik Indonesia Nomor 137 Tahun 2014 tentang Standar PAUD bahwa seharusnya jumlah pendidik dan peserta didik harus sesuai rasio yaitu usia anak 4-6 tahun 1:15, jadi pendidik hanya melayani peserta didik dengan jumlah 15 anak untuk usia 4-6 tahun. (Kemendikbud, 2014) Namun dalam kenyataannya walaupun dengan ketidaksesuaian tersebut, pendidik tetap bersikap adil memberikan pembelajaran kepada semua anak tanpa memilih dan semua anak merasakan sentuhan pembelajaran yang diberikan pendidik. Sebagaimana sesuai hasil penelitian oleh Novan bahwa pendidik PAUD harus memiliki standar kualitas pribadi tertentu yang mencakup tanggung jawab, wibawa, mandiri dan disiplin (Novan, 2015). Bagi peserta didik yang belum memenuhi indikator pencapaian perkembangan, pendidik terus menstimulasi peserta didik tersebut agar indikator perkembangan terpenuhi.

Berdasarkan hasil pengamatan secara performance kedua lembaga cukup berhasil menunjukkan kemampuan dalam mengajar seperti pendidik telah membuat kegiatan pembelajaran sesuai dengan usia anak, walaupun perencanaan pembelajaran tidak didokumentasikan dengan tertib. Pendidik sudah memiliki kreativitas yang cukup baik di 
saat kekurangan bahan pembelajaran atau APE yaitu menggunakan bahan-bahan sekitar anak, teramati dari hasil karya anak. Pendidik memberikan contoh berperilaku yang baik dan berperilaku yang tidak baik, berkata yang baik dan sopan, berpakaian rapi dan murah senyum, dan aktif pada kegiatan-kegiatan yang bertujuan untuk meningkatkan wawasan, keterampilan atau kompetensinya sebagai guru. Tetapi pendidik belum menerapkan model pembelajaran yang beragam yang menumbuhkan rasa penasaran dan keaktifan anak dan/atau pendekatan sainstifik serta pembuatan rencana pembelajaran dan penilaian yang belum dilakukan secara tertib, sehingga kegiatan pembelajaran yang diberikan dan pencapaian perkembangan anak tidak terdokumentasikan dengan baik.

Kepala PAUD di kedua lembaga memiliki latar belakang S1. Selain itu adanya sekretaris dan bendahara yang dimiliki kedua Lembaga PAUD, tetapi dirangkap dengan jabatan lain yaitu di TKS Al-Hidayah Kepala PAUD merangkap sebagai sekretaris dan bendahara dirangkap oleh pendidik, sedangkan di RA Darur Rohmat, Kepala PAUD merangkap sebagai sekretaris dan bendahara. Padahal idealnya tenaga kependidikan tidak merangkap sebagai pendidik sebagaimana penelitian yang dilakukan oleh Anastasia dan Sri Suminar bahwa tugas yang dijalani oleh pengelola Pos PAUD (tenaga kependidikan) sesuai dengan kapasitasnya adalah mengkoordinir semua kegiatan yang ada dalam Pos PAUD, namun ada juga pengelola Pos PAUD yang mengkoordinir sekaligus berperan sebagai pendidik (Adiwirahayu \& Suminar, 2012). Jadi kondisi lembaga pendidikan berpengaruh terhadap pengelolaan tenaga kependidikannya dan lembaga pendidikan yang besar biasanya memiliki tenaga kependidikan yang banyak dan tidak rangkap tugas sebagai pendidik. Walaupun demikian, tetap menjalankan tugas dan fungsi masing-masing jabatan dengan baik.

Sarana dan prasarana yang dimiliki TKS Al-Hidayah untuk kegiatan pembelajaran, administrasi maupun kegiatan lainnya cukup memadai. Sedangkan di RA Darur Rohmat belum memadai. Kedua lembaga sama-sama memiliki luas lahan yang luas. TKS Al-Hidayah terdiri dari 4 ruangan kelas, 1 ruangan guru, 3 kamar mandi, lahan permainan outdoor dan lapangan. RA Darur Rohmat memiliki 2 ruang kelas (1 ruang kelas digabung dengan ruang guru), 1 kamar mandi, lahan permainan outdoor dan lapangan. Tetapi luas bangunan lebih luas TKS Al-Hidayah dibanding RA Darur Rohmat. Penyelenggaraan dan penggunaan lahan di kedua lembaga sudah jelas ijin penyelenggaraannya dan penggunaan lahan. kondisi ruangan kedua lembaga bersih dan tertata rapi. Hal tersebut karena di pagi hari dan sesuai anak pulang dibersihkan oleh guru. Sarana prasarana merupakan tangguang jawab pihak sekolah atau pengelola.(Mursyid, 2016)

Prasarana lain yang dianggap peneliti tidak lengkap di kedua lembaga yaitu belum adanya ruang perpustakaan, ruang unit kesehatan sekolah (UKS), ruang pendidik dan tenaga kependidikan bagi RA Darur Rohmat, ruang serba guna dan dapur. Sedangkan fasilitas cuci tangan bagi TKS Al-Hidayah menggunakan baskom yang disediakan di depan kelas, tetapi di RA Darur Rohmat disediakan di toilet. Terkait kondisi bangunan dan ruang, dapat disimpulkan bahwa gedung bangunan di kedua lembaga PAUD masih kokoh dan dinding sekolah dengan cat yang masih terang sehingga terlihat rapi dan bersih. Lantai ruangan dari keramik dan terlihat selalu bersih. Tetapi dikarenakan RA Darur Rohmat dekat dengan jalan, maka debu pun beterbangan dan masuk ke lantai depan ruangan kelas.

Sumber alat permainan outdoor dan APE lainnya di kedua lembaga diperoleh dari pemerintah. TKS Al-Hidayah memiliki APE yang cukup bervariasi dan dengan jumlah yang cukup untuk anak, sedangkan di RA Darur Rohmat memiliki keterbatasan variasi APE dan jumlah. Kondisi APE di TKS Al-Hidayah tertata rapi disimpan di dalam rak lemari, sedangkan APE Darur Rohmat kurang tertata rapi dan perlunya perbaikan. Padahal APE cukup efektif bagi anak dan lebih mudah dalam mengajar anak-anak karena ada alat peraga atau contoh yang bisa ditiru oleh anak-anak, sehingga pikiran dari anak-anak menjasi terangsang untuk belajar (Rifai, 2014). 
DOI: 10.31004/obsesi.v4i1.259

Kedua lembaga perlu memperhatikan pengelolaan sarana dan prasarana secara keseluruhan sebagai penunjang pembelajaran anak dikarenakan indikator berhasil atau tidaknya proses pencapaian suatu tujuan pendidikan, antara lain dipengaruhi oleh pengelolaan sarana dan prasarana sekolah oleh pihak sekolah (Megasari, 2014).

Pembiayaan sebagai salah satu komponen penting dalam menentukan berjalannya program pendidikan di suatu lembaga pendidikan. Data yang diperoleh dari hasil wawancara dengan Kepala PAUD bahwa dana hanya berasal dari peserta didik yaitu dari SPP. Hasil evaluasi mengenai pembiayaan yang mencakup alokasi dana dan laporan keuangan di kedua lembaga belum sepenuhnya sesuai dengan standar PAUD. Pembiayaan pada kedua lembaga ini meliputi jenis, sumber dan pemanfaatan. Berdasarkan Standar PAUD alokasi pendanaan yang terbesar haruslah diperuntukkan bagi kegiatan yang berhubungan langsung dengan upaya peningkatan standar mutu PAUD. Pencatatan laporan keuangan harus lengkap sebagai kelengkapan administrasi. Pencatatan laporan keuangan yang baik adalah indikasi kemampuan manajerial yang baik.

Komponen process, Perencanaan pembelajaran belum menjamin kesuksesan proses pembelajaran, karena proses penyampaian atau pengimplementasian dari rencana itulah yang justru menentukan efektivitas dari suatu proses pembelajaran. Maka, dalam kaitan dengan evaluasi proses, kedua lembaga belum memenuhi standar PAUD sepenuhnya. Di lapangan, penyusunan RPPM dan RPPH belum dilakukan secara maksimal dan tertib, dikarenakan pendidik merasa sudah memiliki RPPM dan RPPH yang sudah jadi dan terkadang kurang dimodifikasi. Selain itu, jika peserta didik terlalu lama mengerjakan atau bahan pembelajaran tidak tersedia, maka jarang RPPH yang telah dibuat jadi bergeser.

Selama proses pembelajaran, apresiasi peserta didik sangat bervariasi, ada yang antusias memperhatikan, ada yang terlihat tidak memperhatikan, dan ada juga yang mengalihkan perhatiannya pada aktivitas lain seperti bermain sendiri atau berbicara dengan temannya. Bermain pada anak-anak pun mengandung faktor-faktor risiko yang harus diperhatikan agar setiap kegiatan bermain mampu memberikan manfaat sebesar-besarnya bagi anak.(Anhusadar \& Islamiyah, 2019) untuk itu lembaga harus mempertimbangkan faktor keselamatan anak dalam kegiatan bermain.

Seharusnya kegiatan perencanaan pembelajaran dibuat menarik sesuai dengan penelitian Suyatni bahwa perencanaan harus memenuhi aspek-aspek pembelajaran PAUD: aspek apersepsi, aspek kekongkritan, aspek motivasi, aspek bekerja sendiri, aspek bekerja sama, aspek individualisasi, aspek korelasi dan aspek asas belajar seumur hidup, juga memenuhi kebutuhan anak, memperhatikan keamanan, kenyamanan dan keselamatan, dengan prinsip pembelajaran melalui bermain, mendorong kreatifitas, keaktifan maupum mental (Suyatni, Suib, \& Syukri, 2015). Berdasarkan penelitian, kasus kejenuhan yang diperlihatkan peserta didik ditanggapi dengan perkataan untuk diam dan memperhatikan guru. Inti dari mengatasi kejenuhan sebenarnya adalah dengan menarik kembali perhatian peserta didik untuk aktif sepenuhnya dalam pembelajaran. Salah satu langkah yang bisa digunakan oleh pendidik adalah pemberian motivasi dan Wujud pemberian motivasi tidaklah selalu barang tetapi bisa melalui pujian atau kata-kata yang baik untuk peserta didik dengan tujuan untuk membangkitkan motivasi belajar anak atau dengan cara lain menggunakan lingkungan outdoor sebagai tempat belajar anak agar adanya variasi tempat belajar. Oleh karena itu, pendidik harus peka terhadap kebutuhan peserta didik, baik dengan menggunakan berbagai metode atau bahan dan/atau media pembelajaran serta memberikan ruang bagi anak untuk berkreasi.

Dalam melakukan penilaian berdasarkan hasil wawancara dengan Kepala PAUD dan bukti pendukung yang ada bahwa penilaian perkembangan anak dilakukan setiap hari, tetapi tidak didokumentasikan dengan tertib. Penilaian perkembangan anak dilakukan melalui teknik observasi, hasil karya dan catatan anekdot. Penilaian perkembangan observasi di TKS Al-Hidayah menggunakan simbol bintang dan di RA Darur Rohmat menggunakan ceklis. 
Berdasarkan hasil angket orang tua bahwa perencanaan pembelajaran di lembaga kadang-kadang dikomunikasikan kepada orang tua. Berdasarkan hasil wawancara dengan Kepala PAUD, bahkan terkadang orang tua meminta kegiatan pembelajaran yang harus diberikan pendidik kepada anak seperti kegiatan membaca, menulis dan berhitung

Komponen product, perkembangan anak untuk kedua lembaga cukup berkembang dengan baik. Kedua lembaga menggunakan teknik penilaian berbagai macam dalam melakukan penilaian perkembangan. Semua anak di kedua lembaga telah cukup baik memenuhi indikator pencapaian perkembangan. Walaupun dengan kegiatan yang masih monoton, tetapi pendidik terus membantu meningkatkan perkembangan anak bagi anak yang belum memenuhi indikator pencapaian perkembangan. Hal ini perlu terus ditingkatkan oleh pihak sekolah, karena hasil penilaian perkembangan anak sebagai salah satu cermin keberhasilan sekolah dalam mewujudkan visi dan misi sekolah.

Supervisi yang dilakukan di kedua lembaga lebih banyak secara formal, melalui observasi kepada pendidik, dilanjutkan dengan diskusi apa saja kendala yang dihadapi pendidik pada saat proses pembelajaran. Setelah itu pendidik akan menjelaskan permasalahannya lalu diberikan masukan oleh Kepala PAUD. Supervisi yang dilakukan oleh Kepala PAUD sangat memperhatikan rasa kekeluargaan sehingga Kepala PAUD berupaya menjauhkan perasaan kurang nyaman. Namun hasil laporan pengawasan proses pembelajaran hanya dipaparkan setiap akhir semester yang dilaporkan Kepala PAUD kepada orang tua peserta didik.

Supervisi yang dilakukan pendidik memuat mengenai pembelajaran dan penilaian yang dilakukan pendidik untuk anak, tetapi pelaksanaannya tidak dijadwal secara berkala dan tertib. Laporan hasil pengawasan yang dilakukan dengan menggunakan format yang sudah ada dan dalam bentuk angka, tetapi tidak dideskripsikan oleh Kepala PAUD. Pengawasan terhadap proses pembelajaran dan pencapaian perkembangan anak ini dilakukan juga oleh orang tua sesuai dengan hasil angket orang tua bahwa sebagian orang tua terlibat dalam evaluasi pembelajaran dan pencapaian perkembangan anaknya. Hanya saja hal tersebut dilakukan tanpa ada bukti pendukung. Padahal pengawasan dilakukan agar penyelenggaraan program PAUD tidak terjadi penyelewengan atau penyimpanganpenyimpangan serta mengetahui kelemahan-kelemahan program yang dilaksanakan serta menindak pelanggaran-pelanggaran yang terjadi (Rifai, 2014).

Komponen produk ini juga membahas kepuasan orang tua atas pelayanan sekolah. Berdasarkan hasil angket orang tua, semua orang tua menyatakan puas atas layanan sekolah dan pencapaian perkembangan anak yang sudah dicapai anak. Tetapi dalam hal pengawasan dan pembinaan dari instansi terkait, kedua lembaga masih minim dikunjungi.

Berdasarkan hasil wawancara dengan kedua lembaga bahwa lembaga biasa disupervisi dalam waktu yang tidak tentu dan hasil dari kunjungan tersebut tidak diinformasikan kepada lembaga, sehingga lembaga tidak mengetahui hasil dari supervisi tersebut sebagai bahan perbaikan lembaga. Maka dari itu kedua lembaga melakukan pengelolaan lembaga secara mandiri. Padahal pengawasan yang dilakukan pengawas dirasakan membantu guru menguasai materi secara baik, sehingga membantu guru memiliki pengetahuan yang luas tentang bidang studi yang akan berdampak pada penguasaan konsep teoritik secara baik (Gunawan, 2007). Hal ini perlu adanya kerjasama yang baik antara pihak lembaga dan instansi pembina terkait, karena supervisi sebagai salah satu cara dalam mengevaluasi pengelolaan pendidikan atau pembelajaran di lembaga dan peningkatan mutu pendidikan.

\section{KESIMPULAN}

Kedua lembaga PAUD telah memiliki kurikulum sesuai dengan tahapan usia anak, kebutuhan anak, kondisi dan daya dukung lingkungan; memiliki struktur organisasi yang jelas walaupun adanya rangkap jabatan, tetapi tidak mengganggu tugas utama jabatan; peserta didik dikelompokkan berdasarkan usia anak walaupun rasio jumlah ana dan 
DOI: 10.31004/obsesi.v4i1.259

pendidik tidak sesuai; pendidik dan tenaga kependidikan memiliki kompetensi pedagogik, profesional, kepribadian dan sosial yang cukup baik; perencanaan pembelajaran disusun sesuai dengan tahapan usia anak; pelaksanaan penilaian perkembangan anak dilakukan setiap hari; pembiayaan yang didokumentasikan dalam buku kas dengan tertib, perkembangan anak berkembang dengan baik; telah dilakukannya pengawasan Kepala PAUD terhadap proses pembelajaran yang dilakukan oleh pendidik; dan puasnya orang tua anak terhadap layanan pendidikan di kedua lembaga PAUD. Tetapi kedua lembaga PAUD belum melaksanakan evaluasi kurikulum, kegiatan pembelajaran yang masih monoton atau teacher centered, kurangnya pemanfaatan APE dalam mendukung proses pembelajaran, penyusunan pembelajaran yang belum semua disusun sendiri oleh pendidik, penilaian perkembangan harian anak belum didokumentasikan secara berkala dan tertib, dan pengawasan Kepala PAUD yang belum dilakukan secara berkala dan didokumentasikan dengan tertib. Oleh karena itu, pendidik dan tenaga kependidikan diharapkan dapat meningkatkan kompetensi, keterampilan serta kreativitasnya dalam memberikan pendidikan kepada anak usia dini sehingga perkembangan anak berkembang secara optimal dan pendokumentasian perangkat pembelajaran yang dilakukan secara berkala, rapi dan tertib demi tercapainya tujuan pendidikan, serta kerja sama yang baik antara pihak lembaga dan instansi pembina terkait.

\section{UCAPAN TERIMA KASIH}

Terima kasih terutama kepada Ibu Martini Jamaris dan Sri Martini Meilanie atas bimbingan dan dukungan kepada penulis, dan editor serta reviewer Jurnal Obsesi: Jurnal Pendidikan Anak Usia Dini yang telah memberikan masukan dalam penulisan artikel ini.

\section{DAFTAR PUSTAKA}

Adiwirahayu, A., \& Suminar, S. (2012). Strategi Optimalisasi Pengelolaan PAUD Nonformal dalam mewujudkan Prinsip Pendidikan yang mudah murah dan Bermutu di Kecamatan Tegalrejo Kota Yogyakarta. Jurnal Penelitian, 10, 5.

Anhusadar, L. O., \& Islamiyah, I. (2019). Taman Layak Anak Usia Dini di Kota Kendari. Jurnal Obsesi: Jurnal Pendidikan Anak Usia Dini, 3(1), 110. https://doi.org/10.31004/obsesi.v3i1.106

Arikunto, S., \& Jabar, C. S. A. (2009). Evaluasi Program Pendidikan (kedua). Jakarta: Bumi Aksara.

Atmodiwiro, S. (2000). Manejemen Pendidikan Indonesia (p. 5). p. 5. Jakarta: Ardadizya Jaya.

Carol, G. (2007). Developmentally Appropriate Practice (p. 71). p. 71. Canada: Thomson Delmar Learning.

Fleer, M. (1996). Models of Supervision in Early Childhood Programs: Implications for Training. Early Childhood Education Journal, 23(August). https://doi.org/10.1007/BF02353336

Gunawan, G. (2007). Persepsi Guru terhadap Supervisi Pengawas dalam meningkatkan kompetensi profesionalnya di SMA Negeri se-pokja 3 Kab. Sleman. 136(1), 23-42. https://doi.org/10.1007/s00393-018-0552-0

Kasrani. (2016). Evaluasi Program Pendidikan Anak Usia Dini (Paud). Manajemen Pendidikan, 25 (2)(1998), 233-243.

Kemendikbud, R. I. (2014). Permendikbud Nomor 137 Tahun 2014 Tentang Standar Nasional Pendidikan Anak Usia Dini.

Kodarni. (2016). Kualitas Manajemen Kurikulym PAUD IT Cerliana Kota Pekanbaru. Jakarta: UPT Perpustakaan UNJ.

Megasari, R. (2014). Peningkatan Pengelolaan Sarana Dan Prasarana Pendidikan Untuk Meningkatan Kualitas Pembelajaran. Administrasi Pendidikan, 2(1), 1-13.

Mendikbud, \& Indonesia, R. (2014). Permendikbud Nomor 146 Tahun 2014 Tentang Kurikulum 2013 Pendidikan Anak Usia Dini. Kementrian Pendidikan dan Kebudayaan. 
Munthe, A. P. (2015). Pentingnya Evaluasi Program di Institusi Pendidikan. Scholaria, 5, 13. https:// doi.org/10.24246/j.scholaria.2015.v5.i2.p1-14

Murray, J. W. and N. (1990). Children and Movement Physical Education in the Elementary School (p. 139). p. 139. United Statef of America: Wm. C. Brown Communcations, Inc.

Mursyid, M. (2016). The Application of Beyond Centers and Circle Time Approach. Islamic Early Childhood Education P-ISSN:, 1(1), 81-90.

Novan, A. W. M. P. . (2015). Manajemen PAUD Bermutu (p. 77). p. 77. Yogyakarta: Gava Media.

Pendidikan, M., Kebudayaan, D. A. N., \& Indonesia, R. (2019). No Title.

Profile BAN P Banten. (n.d.). Banten: BAN PAUD dan PNF Provinsi Banten.

Ridho, R., Markhamah, \& Darsinah. (2015). Pengelolaan pembelajaran pendidikan anak usia dini (PAUD) di kb "cerdas" kecamatan sukorejo kabupaten kendal. Jurnal Penelitian Humaniora, 16(3), 59-69.

Rifai, S. D. H. dan A. (2014). Penyelengaraan Program di POS PAUD Cinta Ibu di Desa Pangempon Kecamatan Bawang Kabupaten Batang. Journal Unnes, NFECE 3 (2, 62.

Sulusi maizu dan Indah Prabawati. (2016). Implementasi Kebijakan POS PAUD Terpadu Khadijah Kelurahan Kejawanputih Tambak Kecamatan Mulyorejo Kota Surabaya. 01 Nomor $0,9$.

Suyatni, S., Suib, M., \& Syukri, M. (2015). Pengelolaan Program Pendidikan Anak Usia Dini pada Kelompok Bermain. Jurnal Pendidikan Dan Pembelajaran Katulistiwa, 4(8), 11. 